\title{
Pengaruh Self-Esteem dan Optimisme Masa Depan Siswa Menengah Kejuruan (SMK) Berbasis Pesantren
}

\author{
Fia Zahrotun Ni'mah ${ }^{1}$, M. Arif Khoiruddin ${ }^{2}$ \\ ${ }^{1,2}$ Institut Agama Islam Tribakti (IAIT) Kediri \\ ${ }^{1}$ fiazahrotunn@gmail.com², arif@iai-tribakti.ac.id
}

\begin{abstract}
Pesantren-based Vocational Schools are educational institutions with advantages expected to have intellectual, skilful graduates ready to work and uphold morality. This study aims to determine how self-esteem affects the future optimism of Pesantren-based vocational high school students. The study used quantitative methods with a sample of 50 students of SMK Al-Mahrusiyah Pondok Pesantren Lirboyo. Random sampling technique with simple regression analysis. The results showed an influence between self-esteem and optimism of $12.2 \%$ with a significance of 0.013 , meaning that there was a significant contribution of self-esteem and optimism for the future of SMK AlMahrusiyah students. The self-esteem level of SMK Al Mahrusiyah students, the majority of students are at a moderate level of self-esteem of $64 \%$, some others have high self-esteem of $20 \%$, and a smaller portion has a low level of self-esteem of $16 \%$.
\end{abstract}

Keywords: Islamic Boarding Schools, Optimism, Self-Esteem, Vocational Students

\begin{abstract}
Abstrak
Sekolah Menengah Kejuruan (SMK) berbasis pesantren memiliki keunggulan dibandingkan dengan sekolah kejuruan pada umumnya diharapkan lulusannya memiliki intelektual, skill, siap bekerja juga menjunjung tinggi budi pekerti. Tujuan dalam penelitian ini untuk mengetahui bagaimana seft-esteem berpengaruh terhadap optimisme masa depan siswa SMK berbasis pesantren. Penelitian menggunakan metode kuantitatif dengan sampel 50 siswa SMK AlMahrusiyah Pondok Pesantren Lirboyo. Teknik random sampling dengan analisis regresi sederhana. Hasil penelitian menunjukkan terdapat pengaruh antara self-esteem dengan optimisme sebesar 12,2\% dengan signifikasi sebesar 0,013 , artinya terdapat kontribusi signifikan antara self-esteem dan optimisme masa depan siswa SMK Al-Mahrusiyah. Tingkat self-esteem siswa SMK Al Mahrusiyah mayoritas siswa berada pada tingkat self-esteem sedang sebesar $64 \%$, sebagian lain memiliki self-esteem tinggi sebesar $20 \%$ dan sebagian lebih kecil memiliki tingkat self-esteem rendah sebesar $16 \%$.
\end{abstract}

Kata Kunci: Optimisme, Pondok Pesantren, Self-Esteem, Siswa SMK 


\section{Pendahuluan}

Tantangan yang dihadapi bangsa Indonesia saat ini adalah menyediakan sumber daya manusia (SDM) unggul dan berkualitas yang dibekali dengan pengetahuan, keterampilan, sikap, dan moral. Kebutuhan SDM untuk masa depan bangsa tidak hanya menyangkut persoalan kuantitas, tetapi sumber daya manusia yang berkualitas dan berbudi pekerti. Penyelenggaraan pendidikan vokasi berkaitan erat dengan upaya pemenuhan tenaga kerja terampil dan siap pakai. Oleh karenanya, eksistensi pendidikan vokasi memiliki potensi besar dalam rangka pengembangan sumber daya manusia dan mendukung pertumbuhan ekonomi. ${ }^{1}$

Pesantren merupakan salah satu model lembaga pendidikan yang secara khusus diharapkan mampu menanamkan nilai-nilai moral dan sikap positif. Upaya integrasi sistem pendidikan formal dan pondok pesantren banyak dilakukan, sekolah umum dan pesantren yang masing-masing memiliki keunggulan tersendiri juga memiliki kelemahan atau kekurangan. Sekolah umum di luar pondok pesantren memiliki keunggulan dalam aspek hardskill dan pesantren unggul dalam aspek softskill. Jika dipadukan akan menciptakan pendidikan yang berpotensi kuat melahirkan generasi muda bangsa Indonesia yang handal dan unggul dengan semangat akhlak mulia yang mampu bersaing di era global. Selain memiliki kedalaman ilmu agama, lulusan pondok pesantren juga memiliki keterampilan sebagai pengembangan individu di era global. ${ }^{2}$ Sekolah vokasi atau SMK berbasis pesantren tujuan utamanya mencetak generasi bangsa yang memiliki intelektual, skill, siap bekerja juga menjunjung tinggi akhlakul karimah. Lulusan SMK berbasis pesantren diharapkan mampu melahirkan lulusan sesuai dengan bidang keahlian yang memiliki interpersonal skill dan juga memiliki kecakapan dalam agama terlebih pada pendidikan karakter. ${ }^{3}$

Norma dalam ajaran agama diyakini menjadi media paling efektif dalam meminimalkan perilaku negatif umumnya siswa SMK yang berada di luar pesantren seperti sikap acuh tak acuh siswa terhadap guru dan orang tua, labilnya kontrol emosi karena minimnya interaksi dengan orang lain, penyalahgunaan narkoba, pergaulan bebas, depresi,

\footnotetext{
${ }^{1}$ Umi Rochayati, Z. Zamroni, and Putu Sudira, "Islamic Boarding School Based Vocational Education: A Case Study on SMK Syubbanul Wathon Tegalrejo Magelang," Jurnal Pendidikan Vokasi 7, no. 3 (2017): 263, https://doi.org/10.21831/jpv.v7i3.12450.

${ }^{2}$ Rochayati, Zamroni, and Sudira, 263.

${ }^{3}$ Ece Supriatna et al., "Konsep dan Implementasi Pendidikan Karakter di Sekolah Menengah Kejuruan (SMK) Berbasis Pondok Pesantren," Ta'dibuna: Jurnal Pendidikan Islam 3, no. 2 (September 5, 2014): 104, https://doi.org/10.32832/tadibuna.v3i2.564.
} 


\section{Self-Esteem dan Optimisme..., Fia Zahrotun N, M. Arif Khoiruddin}

kecemasan sosial dan perilaku menyimpang yang lain. ${ }^{4}$ Siswa lulusan SMK berbasis pesantren diharapkan lebih optimis karena pendidikan agama membentuk keyakinan lebih percaya Tuhan yang menentukan nasib kehidupan setelah lulus termasuk penilaian diri sendiri dibandingkan dengan siswa SMK umum. Pengetahuan umum diseimbangkan dengan pengetahuan agama yang jelas membuat mereka bernilai lebih, dengan demikian akan mampu menambah rasa optimisme masa depan. Pengembangan sumber daya manusia melalui pendidikan SMK berbasis pesantren memiliki keunggulan dibandingkan dengan sekolah kejuruan pada umumnya seperti nilai moral dan sikap positif dapat ditanamkan kepada siswa melalui lembaga pendidikan ini termasuk dapat mengembangkan tiga nilai sekaligus yaitu pengembangan pengetahuan dan ketrampilan, moral atau karakter dan juga spiritual.

Salah satu kebijakan yang diterapkan pemerintah pusat pada tahun 2008 dengan membuat program SMK berbasis pesantren. Melalui kebijakan ini santri yang belajar ilmu agama di pondok pesantren juga mendapatkan kesempatan untuk mengembangkan diri lebih baik dan bisa terampil dan mampu bersaing pada dunia kerja. Selain itu harapannya setelah lulus dapat mengurangi angka pengangguran dan memberikan kesempatan kerja bagi setiap orang yang membutuhkan. Keunikan dan keunggulan yang dimiliki pondok pesantren dapat menjadi alternatif pendidikan bagi vokasi di Indonesia yang menyediakan tenaga kerja terampil sekaligus berbudi pekerti mulia dan benar-benar menjadi pendukung utama dalam menunjang pertumbuhan dan perekonomian bangsa. ${ }^{5}$

Pemerintah Indonesia memberikan perhatian besar pada pendidikan vokasi dengan berbagai kebijakan yang mendukung pembangunan dalam bidang ekonomi dan pendidikan. ${ }^{6}$ Pada tahun 2014 pemerintah Indonesia mengeluarkan kebijakan pendidikan melalui Kementerian Pendidikan dan Kebudayaan dengan meningkatkan jumlah SMK dari SMA menjadi 60:40. ${ }^{7}$ Dengan kebijakan pembatasan pendirian SMA yang dilakukan pemerintah, banyak pondok pesantren yang di dalamnya juga menyelenggarakan pendidikan formal yang mendirikan SMK. Pemerintah Jawa Timur pada tahun 2014 memberikan stimulasi dana

\footnotetext{
${ }^{4}$ Kholilur Rahman, "Inovasi Pendidikan Keahlian Sekolah Menengah Kejuruan Berbasis Pesantren di Kabupaten Banyuwangi," Jurnal Pendidikan Agama Islam (Journal of Islamic Education Studies) 6, no. 2 (2018): 241, https://doi.org/10.15642/jpai.2018.6.2.225-252.

${ }^{5}$ Rochayati, Zamroni, and Sudira, "Islamic Boarding School Based Vocational Education," 264.

${ }^{6}$ Sudiyatno Sudiyatno et al., "The Effect of Instructional Quality on Vocational Students' Academic Achievement and Career Optimism," International Journal of Innovation, Creativity and Change 10, no. 7 (2019): 244.

${ }^{7}$ Mukhammad Syaom Barliana, Djohar Maknun, and Kunthi Herman, "Evaluasi Atas Kebijakan Peningkatan Rasio Siswa SMK:SMA Ditelaah Dari Kesiapan Sarana Dan Prasarana," Invotec 6, no. 2 (2010): 531, https://doi.org/10.17509/invotec.v6i2.6087.
} 
hibah masing-masing sebesar 250 juta bagi pendirian SMK mini di beberapa pesantren. Pemerintah pusat pada tahun 2016 juga memberikan bantuan pembangunan dan renovasi hampir 171 miliar rupiah bagi SMK berbasis komunitas termasuk SMK berbasis pesantren. ${ }^{8}$

Fenomena maraknya pondok pesantren yang mendirikan sekolah kejuruan adalah dalam upaya untuk memberikan pengetahuan dan keterampilan kepada santri, serta memberikan ijazah formal jika santri akan bekerja di dunia kerja atau jika santri ingin melanjutkan pendidikan ke jenjang yang lebih tinggi. Penyelenggaraan pendidikan vokasi di pondok pesantren adalah untuk memberikan keterampilan kepada santri untuk berpartisipasi aktif di masyarakat. Melalui pendidikan vokasi ini para siswa yang sekaligus santri dilatih dan dibekali keterampilan yang sesuai dengan kebutuhan pekerja dengan landasan keagamaan yang kuat. Jadi konsep dasar pendirian pendidikan vokasi di pondok pesantren adalah konsep dasar kebutuhan lapangan kerja. Pesantren ingin memberikan kontribusi kepada masyarakat dengan menciptakan kader-kader yang memiliki keterampilan kerja, dan memiliki landasan keagamaan yang kuat. Pada abad ini dunia kerja membutuhkan tenaga kerja yang tidak hanya memiliki hard skill tetapi juga soft skill dan religiusitas yang kuat. ${ }^{9}$

Selain memiliki keunggulan, pendidikan formal di pondok pesantren juga memiliki tantangan dan permasalahan yang dihadapi baik secara akademik maupun non-akademik. Seperti minimnya kualitas tenaga pengajar profesional dibandingkan dengan sekolah umum di luar pesantren, fasilitas pendukung dan praktik pembelajaran terbatas. Selain itu siswa SMK yang juga berstatus santri terkadang belum totalitas dalam belajar, padatnya kegiatan sehari-hari pondok pesantren, sarana pendukung dan praktik magang yang terbatas tidak jarang menimbulkan keminderan siswa, persaingan di dunia kerja lebih luas dari pada kehidupan di lingkungan pesantren. Optimisme mereka dalam menghadapi kehidupan setelah mereka lulus sangat memengaruhi mereka dalam kesungguhan belajar selama di lingkungan sekolah. Sikap optimis sangat dibutuhkan untuk menempuh tujuan atau masa depan yang mereka inginkan. ${ }^{10}$

Individu yang memiliki pola pikir optimis memiliki rasa percaya diri dan merasa bahagia dalam menjalankan kehidupan sehari-hari. Sikap optimis harus menjadi bagian dalam kehidupan siswa yang akan berpengaruh secara langsung dalam kegiatan belajarnya. ${ }^{11}$

\footnotetext{
${ }^{8}$ Siti A'isyah, "SMK Pesantren: Sebuah Penelusuran Akar Ideologi Pendidikan," Dirasat: Jurnal Manajemen dan Pendidikan Islam 3, no. 1 (December 1, 2017): 83, https://doi.org/10.26594/dirasat.v3i1.986.

${ }^{9}$ Rochayati, Zamroni, and Sudira, "Islamic Boarding School Based Vocational Education," 264.

${ }^{10}$ Ajeng Astari, Wawancara dengan Pengurus Pondok Pesantren Al-Mahrusiyyah, July 23, 2020.

${ }^{11}$ Ruth Novianti Sidabalok, Winida Marpaung, and Yulinda Septiani Manurung, "Optimisme dan Self Esteem pada Pelajar Sekolah Menengah Atas," Philanthropy: Journal of Psychology 3, no. 1 (July 25, 2019): 55, https://doi.org/10.26623/philanthropy.v3i1.1319.
} 
Dengan sikap optimis membuat individu mampu lebih cepat dan tanggap dalam menanggapi masalah yang dihadapi, mempunyai harapan masa depan positif, tidak memikirkan hal-hal negatif dan bisa bertahan saat menghadapi berbagai kesulitan. ${ }^{12}$

Optimisme merupakan cara berpikir secara positif, sikap yang baik dan pandangan terhadap masa depan pada diri individu dengan kecenderungan memiliki harapan besar terhadap keseluruhan hidup secara positif meskipun dihadapkan pada persoalan dan kesulitan. Selain itu, mereka mengemukakan bahwa optimisme dikaitkan dengan kecenderungan untuk fokus pada pemecahan masalah ketika itu terjadi di bawah situasi tekanan dan untuk tidak menghindar dan menolak masalah yang dihadapi. ${ }^{13}$

Pentingnya sikap optimisme bagi individu, McGinnis menjelaskan ciri-ciri orang yang optimis di antaranya mereka tidak mudah putus asa jika mengalami kesulitan dan berani menghadapi kenyataan, kemudian mampu memecahkan berbagai macam permasalahan yang sedang dihadapi, sebesar apapun masalahnya dapat diselesaikan. Lebih lanjut ciri orang yang optimis mampu mengendalikan masa depan karena merasa yakin dirinya mempunyai kekuatan untuk menghadapinya, memungkinkan untuk melakukan pembaruan secara teratur, menghentikan pemikiran yang negatif dan menggantinya dengan yang lebih logis serta mengubah kekhawatiran menjadi bayangan yang positif, meningkatkan kekuatan apresiasi dalam dirinya serta membina cinta dalam kehidupan dan menerima apa yang tidak bisa diubah. ${ }^{14}$

Tinggi rendahnya optimisme masa depan salah satunya dipengaruhi oleh self-esteem yang merupakan penilaian individu yang mengandung penghargaan terhadap dirinya sendiri. Self-esteem merupakan penilaian positif terhadap diri sendiri akan kemampuan yang dimiliki, keterampilan dan hubungan sosial. Self-esteem merupakan persepsi tentang harga diri, perasaan dan kepercayaan diri sejauh mana memandang positif atau negatif tentang dirinya sendiri. ${ }^{15}$ Menurut psikolog self-esteem penting karena menandakan seberapa baik seseorang diterima atau dihargai secara budaya. Dengan demikian orang akan termotivasi untuk mencari dan mempertahankan harga diri yang tinggi dengan cara yang beragam.

\footnotetext{
${ }^{12}$ University of Athens, Greece et al., "Optimism, Career Decision Self-Efficacy and Career Indecision Among Greek Adolescents," Education Quarterly Reviews 2, no. 1 (March 30, 2019): 186, https://doi.org/10.31014/aior.1993.02.01.52.

13 Sayidah Aulia and Iwan Widayat, "Optimism Overview of a Kyai in Life and Running an Islamic Boarding School,” vol. 6 (Kyoto, Japan: ISEP, 2017), 273.

${ }^{14}$ Alan L McGinnis, Kekuatan Optimisme (Jakarta: Mitra Utama, 1995), 11.

${ }^{15}$ Franklin Holloway, ed., Self-Esteem: Perspectives, Influences and Improvement Strategies, Psychology of Emotions, Motivations and Actions (New York: Nova Science Publishers, Inc, 2016), 1.
} 
Kebanyakan orang memiliki self-esteem yang relatif tinggi, meskipun tingkatannya bervariasi tergantung pada pengalaman penerimaan interpersonal. ${ }^{16}$

Idealnya semakin tinggi self-esteem yang dimiliki seseorang maka optimisme masa depan juga semakin tinggi. Jika self-esteem positif dengan kemampuan yang dimiliki maka tingkat optimisme masa depan juga akan tinggi. Begitu sebaliknya jika menilai diri sendiri negatif dan banyak kelemahannya maka tingkat optimisme masa depanpun rendah. Optimisme dan self-esteem merupakan faktor yang berperan penting dalam mengatasi tekanan psikologis. Banyak riset sebelumnya membahas tentang SMK berbasis pesantren baik dari sisi keungggulan, konsep dan implementasinya dalam membentuk karakter dan interpersonal skill, namun bagaimana self-esteem maupun optimisme masa depan siswa tersebut belum banyak dikemukakan. Untuk itu hasil penelitian ini penting guna mengetahui bagaimana pengaruh seft-esteem terhadap optimisme masa depan siswa SMK yang berada di pondok pesantren.

\section{Metode}

Penelitian dilakukan dengan menggunakan metode penelitian kuantitatif dengan jumlah populasi sebanyak 294 siswa yang ada SMK Al-Mahrusiyah Lirboyo Kediri. Pengambilan sampel sebanyak 50 siswa dengan menggunakan teknik random sampling. Pengumpulan data diperoleh melalui pengisian Instrumen penelitian berupa angket yang disusun sebagaimana dikemukakan Minchinton dengan item yang ada pada self-esteem mengenai perasaan terhadap diri sendiri, perasaan terhadap orang lain, dan perasaan yang berhubungan dengan orang lain. Sedangkan angket optimisme masa depan disusun oleh Ubaidillah dengan item pengembangan optimisme yaitu kognitif, afektif, dan konatif. Di samping itu, peneliti juga melakukan observasi, dokumentasi, dan wawancara. Wawancara dilakukan untuk mendapatkan informasi sebagai studi pendahuluan dan untuk mengetahui lebih mendalam terhadap beberapa responden. Sedangkan teknik analisis data menggunakan regresi linier sederhana menggunakan program IBM SPPS Statistics 20.

16 E.G. Hepper, "Self-Esteem," in Encyclopedia of Mental Health (Elsevier, 2016), 80-91, https://doi.org/10.1016/B978-0-12-397045-9.00076-8. 
Self-Esteem dan Optimisme..., Fia Zahrotun N, M. Arif Khoiruddin

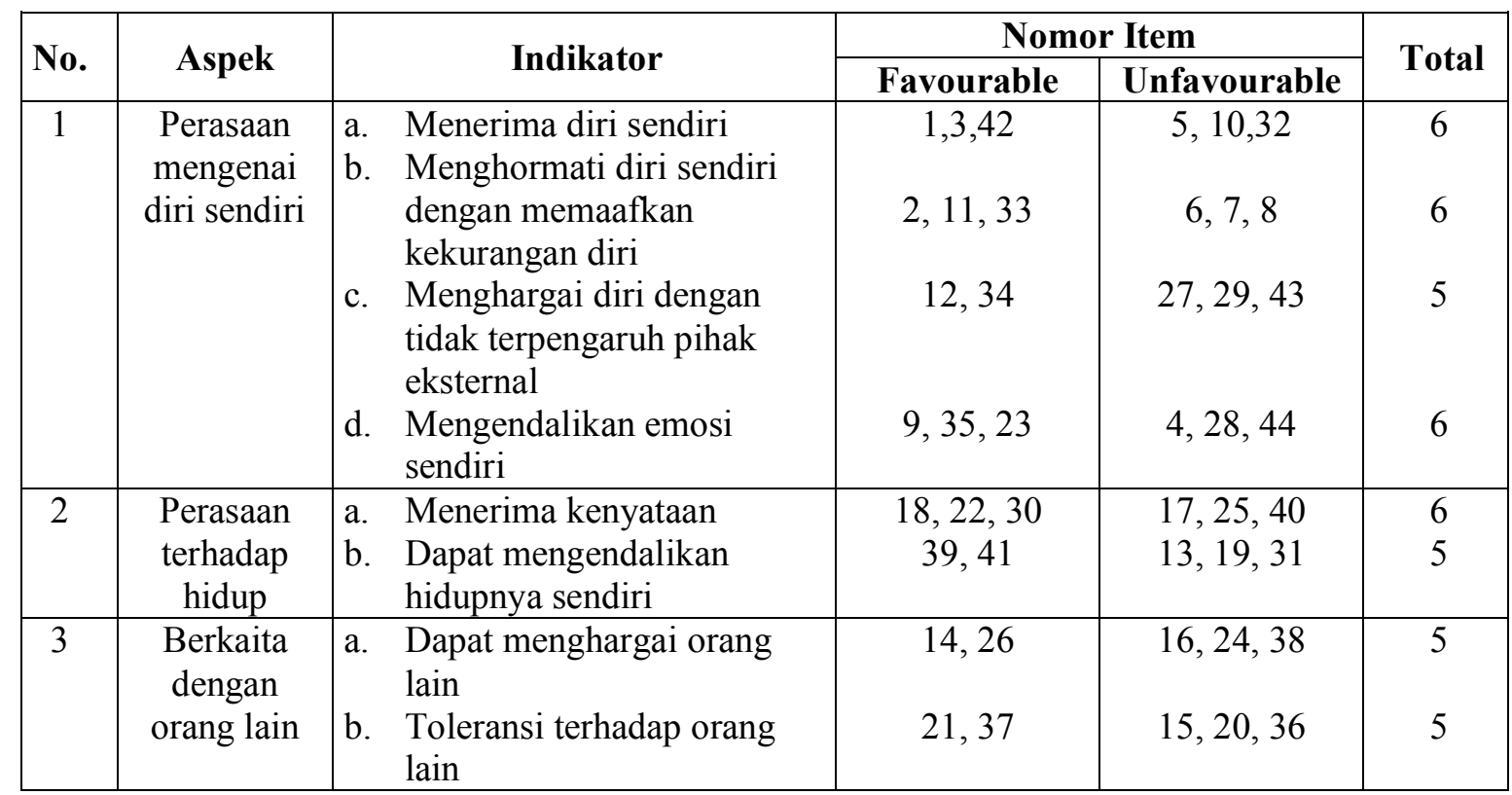

Tabel 1. Blue Print Self-esteem (try out)

\begin{tabular}{|c|c|c|c|c|c|}
\hline \multirow[t]{2}{*}{ No. } & \multirow[t]{2}{*}{ Aspek } & \multirow[t]{2}{*}{ Indikator } & \multicolumn{2}{|c|}{ Nomor Item } & \multirow[t]{2}{*}{ Total } \\
\hline & & & Favourable & Unfavourable & \\
\hline 1 & Kognitif & $\begin{array}{l}\text { a. Percaya diri dan memiliki } \\
\text { kemauan serta harapan } \\
\text { b. Mempunyai rencana yang } \\
\text { terfokus pada hasil yang } \\
\text { lebih baik } \\
\text { c. Positif dan realistis } \\
\text { terhadap fakta }\end{array}$ & $\begin{array}{c}1,2,3 \\
5,7,9,19\end{array}$ & $\begin{array}{r}4,10,25 \\
27,30,33\end{array}$ & $\begin{array}{l}6 \\
7\end{array}$ \\
\hline 2 & Afektif & $\begin{array}{l}\text { a. Tidak memperbesar } \\
\text { masalah } \\
\text { b. Memiliki perasaan positif } \\
\text { atas kemampuan yang } \\
\text { dimiliki } \\
\text { c. Mampu menghayati hidup } \\
\text { dan membedakan hal yang } \\
\text { salah dan benar }\end{array}$ & $\begin{array}{r}6,12,16 \\
17,21,22\end{array}$ & $\begin{array}{r}8,14,15 \\
18,29,35\end{array}$ & $\begin{array}{l}6 \\
6\end{array}$ \\
\hline 3 & Konatif & $\begin{array}{ll}\text { a. } & \text { Berperilaku lebih baik } \\
\text { untuk menghasilkan yang } \\
\text { lebih baik } \\
\text { b. } \\
\text { Mampu menjalankan } \\
\text { agenda secara kontinyu }\end{array}$ & $13,20,26,37$ & $11,23,28,31$ & 8 \\
\hline
\end{tabular}

Tabel 2. Blue Print Optimisme Masa Depan (try out)

Perolehan data variabel self-esteem melalui angket kuesioner dengan jumlah 50 responden berasal dari siswa diperoleh skor dengan hasil tertinggi adalah 94; skor terendah adalah 71; nilai rata-rata sebesar 80,56; nilai median sebesar 80; nilai modus sebesar 80 ; nilai standar deviasi sebesar 5,821. Hasil tersebut dapat dilihat sebagaimana tabel 3: 


\begin{tabular}{|l|c|c|}
\hline \multirow{2}{*}{\multicolumn{1}{|c|}{$\mathrm{N}$}} & $\mathrm{N}$ & 50 \\
\cline { 2 - 3 } & Valid & 0 \\
\hline Mean & Missing & 80,56 \\
\hline Std. Error of Mean & 0,82321 \\
\hline Median & 80,000 \\
\hline Mode & $80,0^{\mathrm{a}}$ \\
\hline Std. Deviation & 5,821 \\
\hline Variance & 33,884 \\
\hline Range & 23 \\
\hline Minimum & 71 \\
\hline Maximum & 94 \\
\hline
\end{tabular}

Tabel 3. Nilai Mean, Median, Modus, Standar Deviasi Self-esteem

Tingkatan optimisme masa depan digolongkan dalam tiga kategori yaitu tinggi, sedang dan rendah. Sebaran kategori skor sebagaimana dalam tabel 4:

\begin{tabular}{|c|c|c|c|c|}
\hline Kategori & & Rentang & Frekuensi & $\%$ \\
\hline Tinggi & $\geq M+1 S D$ & $\geq 86$ & 10 & $20 \%$ \\
\hline Sedang & $\begin{array}{c}M-1 \mathrm{SD} \leq \mathrm{X}< \\
\mathrm{M}+1 \mathrm{SD}\end{array}$ & $75-86$ & 32 & $64 \%$ \\
\hline Rendah & $\leq \mathrm{M}-1 \mathrm{SD}$ & $\leq 75$ & 8 & $16 \%$ \\
\hline Jumlah & & & 50 & $100 \%$ \\
\hline
\end{tabular}

\section{Tabel 4. Kategori Self-esteem}

Skor self-esteem hasil perhitungan kategori sebagaimana dalam tabel 4 diperoleh sebesar 20\% siswa memiliki tingkat self-esteem tinggi, 64\% tingkat sedang, dan 16\% tingkat rendah.

\begin{tabular}{|l|r|r|}
\hline \multicolumn{1}{|c|}{ N } & N & \multicolumn{1}{|c|}{50} \\
\cline { 2 - 3 } & Valid & 0 \\
\hline Mean & Missing & 80,5600 \\
\hline Std. Error of Mean & 0,82321 \\
\hline Median & 80 \\
\hline Mode & $80^{\mathrm{a}}$ \\
\hline Std. Deviation & 5,821 \\
\hline Variance & 33,884 \\
\hline Range & 23 \\
\hline Minimum & 71 \\
\hline Maximum & 94 \\
\hline
\end{tabular}

Tabel 5. Standar Deviasi optimisme masa depan

Variabel optimisme masa dilakukan analisis diperoleh skor tertinggi adalah 94; skor terendah adalah 71; nilai nilai mean $(\mathrm{M})$ sebesar 80,560; nilai median $(\mathrm{Me})$ sebesar 80; nilai modus (Mo) sebesar 80; nilai standar deviasi (SD) sebesar 5,821. 


\begin{tabular}{|c|c|c|c|c|}
\hline Kategori & & Rentang & Frekuensi & $\%$ \\
\hline Tinggi & $\geq \mathrm{M}+1 \mathrm{SD}$ & $\geq 86$ & 10 & $20 \%$ \\
\hline Sedang & $\begin{array}{c}\mathrm{M}-1 \mathrm{SD} \leq \mathrm{X}< \\
\mathrm{M}+1 \mathrm{SD}\end{array}$ & $75-86$ & 32 & $64 \%$ \\
\hline Rendah & $\leq \mathrm{M}-1 \mathrm{SD}$ & $\leq 75$ & 8 & $16 \%$ \\
\hline Jumlah & & & 50 & $100 \%$ \\
\hline
\end{tabular}

Tabel 6. Kategori Optimisme Masa Depan

Hasil perhitungan berdasarkan pengategorian skor self-esteem sebagaimana hasil yang dipaparkan dalam tabel 6 diperoleh sebesar 20\% siswa SMK Al-Mahrusiyah memiliki tingkat optimisme masa depan tinggi, 64\% dengan tingkat kategori sedang dan 16\% masuk kategori rendah.

\begin{tabular}{|l|r|r|r|r|r|rr|}
\hline & \multicolumn{4}{|c|}{ Kolmogorov-Smirnov } & \multicolumn{3}{c|}{ Shapiro-Wilk } \\
\cline { 2 - 8 } & Statistic & \multicolumn{1}{c|}{ Df } & \multicolumn{1}{c|}{ Sig. } & Statistic & \multicolumn{1}{c|}{ df } & Sig. \\
\hline self-esteem &, 107 & 50 &, $200^{*}$ &, 973 & 50 &, 293 \\
\hline optimisme &, 098 & 50 &, $200^{*}$ &, 965 & 50 &, 148 \\
\hline
\end{tabular}

Tabel 7. Uji Normalitas Tests of Normality

Adapun hasil yang diperoleh dari uji normalitas dengan teknik kolmogorof smiirnov didapat signifikansi self-esteem sebesar 0,200 dengan nilai signifikansi optimisme masa depan sebesar 0,200, dengan demikian hasil uji data berdistribusi normal.

\begin{tabular}{|c|c|c|c|c|}
\hline Model & $\mathrm{R}$ & R Square & $\begin{array}{l}\text { Adjusted R } \\
\text { Square }\end{array}$ & $\begin{array}{l}\text { Std. Error of } \\
\text { the Estimate }\end{array}$ \\
\hline 1 &, $350^{\mathrm{a}}$ & ,122 &, 104 & 5,50961 \\
\hline
\end{tabular}

Tabel 8. Uji Regresi Linear Sederhana Model Summary

$\mathrm{R}$ square koefisien determinasi sebesar $12,2 \%$ atau 0,122 . Kesalahan standar (Se) sebesar 5,509. Hasil tersebut menunjukkan bahwa kontribusi variabel bebas terhadap variabel terikat sebesar $12,2 \%$, sedangkan untuk sisanya sebesar $87,8 \%$ merupakan variabel lain yang tidak diteliti

\begin{tabular}{clrrrrr} 
Model & & Sum of & Df & Mean Square & F & \multicolumn{1}{l}{ Sig. } \\
& & Squares & & & & \\
& Regression & 203,239 & 1 & 203,239 & 6,695 &, $013^{\text {b }}$ \\
1 & Residual & 1457,081 & 48 & 30,356 & & \\
& Total & 1660,320 & 49 & & &
\end{tabular}

a. Dependent Variable: optimisme

b. Predictors: (Constant), self-esteem

Tabel 9. Anova ${ }^{a}$

Tabel 9 menunjukkan besarnya nilai $\mathrm{F}$ hitung $=$ 6,695 dengan derajat kebebasan pembilang df1 dan df2 $=48$, pada kolom signifikan sebesar 0,013. Dengan demikian siswa yang ada di SMK Al-Mahrusiyyah memiliki tingkat self-esteem tinggi berhubungan dengan optimisme masa depan. 
Self-Esteem dan Optimisme..., Fia Zahrotun N, M. Arif Khoiruddin

\begin{tabular}{|l|l|r|r|r|r|r|}
\hline \multicolumn{2}{|l|}{ Model } & \multicolumn{2}{|l|}{ Unstandardized Coefficients } & $\begin{array}{c}\text { Standardized } \\
\text { Coefficients }\end{array}$ & \multirow{2}{*}{ T } & \multirow{2}{*}{ Sig. } \\
\cline { 3 - 5 } \multicolumn{2}{|l|}{} & \multicolumn{1}{|c|}{ B } & Std. Error & Beta & & \\
\hline \multirow{2}{*}{1} & (Constant) & 57,490 & 8,950 & & 6,424 &, 000 \\
\cline { 2 - 7 } & self-esteem &, 237 &, 092 &, 350 & 2,588 &, 013 \\
\hline
\end{tabular}

Tabel 10. Uji Coefficients ${ }^{\mathrm{a}}$

Tabel 10 menunjukkan hasil nilai $\mathrm{t}$ test $=2,588$ dengan Signifikasi sebesar 0,013, artinya terdapat kontribusi signifikan self-esteem dan optimisme masa depan siswa SMK A1Mahrusiyah.

\section{Pembahasan}

\section{Self-esteem Siswa SMK dipondok Pesantren Al-Mahrusiyyah}

Hasil penelitian menunjukkan self-esteem berpengaruh terhadap optimisme masa depan seorang siswa SMK di pondok pesantren Al-Mahrusiyyah meskipun hanya sebesar $12,2 \%$ artinya tingkat self-esteem pada siswa SMK Al-Mahrusiyah mayoritas berada pada tingkat self-esteem yang sedang sebesar 64\%, sebagian yang lain memiliki self-esteem tinggi sebesar 20\% dan sebagian lebih kecil memiliki tingkat self-esteem rendah sebesar 16\%. Ada faktor lain yang dapat memengaruhi optimisme masa depan siswa di SMK Al-Mahrusiyah dan sebagian siswa masih menilai dirinya cukup mampu untuk bisa bersaing dan meraih masa depan sesuai dengan harapan dan cita-cita yang mereka inginkan. Dengan hasil ini sebenarnya sudah memenuhi sebagian besar aspek dalam self-esteem, namun tingkat selfesteem mereka dapat dikembangkan dan menetap seiring mereka berkembang secara sosial.

Hal ini sebagaimana penelitian Aisyah berkaitan dengan optimisme masa depan santri di pondok pesantren tahfidz yang menunjukkan terdapat hubungan signifikan antara self-esteem berpengaruh positif terhadap optimisme masa depan santri. ${ }^{17}$ Penelitian Endang Multasih dan Bambang Suryadi juga menunjukkan hubungan self-esteem, dukungan sosial dan optimisme masa depan anak jalanan, semakin tinggi self-esteem dan dukungan sosial maka semakin tinggi pula optimisme masa depan. ${ }^{18}$ Menurut Seligman, self-esteem hanya mewakili satu dari beberapa hal yang mempengaruhi optimisme, ada faktor lain yang

\footnotetext{
${ }^{17}$ Siti Aisyah, Susatyo Yuwono, and Saifuddin Zuhri, "Hubungan Self Esteem dengan Optimisme Masa Depan Santri Program Tahfidz di Pondok Pesantren Al Muayyad Surakarta dan Ibnu Abbas Klaten. Jurnal Indeginous," Indigenous: Jurnal Ilmiah Psikologi 13, no. 2 (November 12, 2015): 6, http://journals.ums.ac.id/index.php/indigenous/article/view/2598.

${ }^{18}$ Endang Multasih and Bambang Suryadi, "Pengaruh Self-Esteem Dan Dukungan Sosial Terhadap Optimisme Masa Depan Anak Jalanan Di Rumah Singgah Jakarta Selatan," TAZKIYA: Journal of Psychology 1, no. 1 (February 21, 2019): 67, https://doi.org/10.15408/tazkiya.v18i1.9377.
} 
mempengaruhi optimisme di antaranya kepercayaan diri, akumulasi pengalaman sukses, dan dukungan sosial. ${ }^{19}$

Berdasarkan informasi siswa SMK Al-Mahrusiyah yang memiliki tingkat self-esteem sedang, mereka merasa minder dan tidak begitu yakin dengan kemampuan yang mereka miliki selama mengikuti proses belajar di SMK, minimnya pengalaman praktik yang didapatkan dan terbatasnya aturan pondok pesantren yang hanya memperbolehkan siswa magang kerja di sekolah sendiri menjadi salah satu faktor yang memengaruhi rendahnya self-esteem, meskipun pihak sekolah saat praktik magang menghadirkan guru produktif dari luar.

Selain itu sarana penunjang pembelajaran terhambat dengan aturan pondok seperti SMK jurusan multimedia. Siswa yang belajar mengambil gambar atau foto, membuat film pendek, editing video, mendesain dan semacamnya namun aturan pondok melarang membawa kamera ataupun laptop saat mereka berada di pondok pesantren. Di sekolah fasilitas terbatas membawa laptop namun boleh digunakan saat pelajaran di kelas saja, ketika berada di pondok pesantren tidak diperbolehkan. SMK Jurusan Teknik Komputer dan Jaringan (TKJ) tidak kalah terbatasnya dengan siswa jurusan multimedia. Mereka belajar bongkar pasang laptop namun hanya boleh diambil ketika praktik. Untuk belajar jaringan, perangkat yang disediakan juga tidak maksimal. ${ }^{20}$

Dengan memberikan kesempatan magang di luar sekolah, melonggarkan peraturan pondok untuk mendukung kratifitas siswa dan juga memberikan fasilitas penunjang pembelajaran yang memadai, guru bimbingan konseling juga dibutuhkan untuk mengetahui faktor-faktor yang memengaruhi sedang atau rendahnya self-esteem siswa SMK di pondok pesantren termasuk mengembangkan program kegiatan bimbingan yang tujuannya meningkatkan seft-esteem dan mengurangi tingkat kecemasan siswa dalam kondisi yang tidak pasti bahkan cenderung negatif. ${ }^{21}$ Salah satu faktor yang memengaruhi self-esteem yaitu lingkungan sosial. Pembentukan harga diri dimulai dari kesadaran individu tentang berharga atau tidaknya individu tersebut merupakan hasil dari proses lingkungan, penghargaan, penerimaan orang lain terhadap dirinya

Pengembangan self-esteem dalam pendidikan terutama di pondok pesantren penting dilakukan untuk mengubah, mengembangkan, dan menemukan konsep diri positif pada jiwa

\footnotetext{
${ }^{19}$ Martin E. P Seligman, Learned Optimism (New York, NY: Knopf, 1991).

${ }^{20}$ Astari, Wawancara dengan Pengurus Pondok Pesantren Al-Mahrusiyyah.

${ }^{21}$ Elpida Bagana, Andreea Raciu, and Luminita Lupu, "Self Esteem, Optimism and Exams' Anxiety among High School Students," Procedia - Social and Behavioral Sciences, 2nd World Conference on Psychology, Counselling and Guidance - 2011, 30 (January 1, 2011): 1332, https://doi.org/10.1016/j.sbspro.2011.10.258.
} 
siswa yang akan menentukan keberhasilan ataupun kegagalan siswa di masa mendatang, orang-orang penting di sekitar mereka. ${ }^{22}$ Self-esteem pada siswa SMK secara positif akan terbentuk dan menetap dalam diri didukung lingkungan sosial yang ada di pondok pesantren. Sebagaimana ajaran agama mengatakan manusia memiliki amanat yang luar biasa dalam menjalani kehidupan sebagai hamba Allah. Harga diri juga akan tumbuh dari hasil pengalaman dan interaksi sosial baik itu menyenangkan ataupun tidak yang akan membentuk harga diri secara positif ataupun negatif. Seiring dengan bertambahnya usia, harga diri dan perasaan akan cenderung lebih stabil dan tidak fluktuatif jika dihadapkan dengan berbagai pengalaman dan persoalan yang berbeda. ${ }^{23}$

Sumber penting dalam pembentukan dan pengembangan self-esteem di antaranya pengaruh keluarga. Di pondok pesantren peran ini digantikan oleh pembina asrama. Interaksi sosial yang baik dan menyenangkan akan membentuk harga diri positif maupun negatif. Perkembangan self-esteem tersebut akan dirasakan secara bertahap ketika mereka mulai mengenal jauh siapa diri mereka sendiri dan mengenali bahwa orang lain berbeda. Terlebih mereka adalah individu yang berpisah dengan orang tua yang secara tidak langsung memaksa mereka untuk segera tumbuh dalam kehidupan mereka sendiri hingga akhirnya mereka menemukan siapa diri mereka sebenarnya. Maka peran penting pembina asrama sebagai pengganti orang tua siswa saat berada di pondok dibutuhkan untuk menumbuhkan dan membentu self-esteem pada diri santri saat berada di pondok pesantren. ${ }^{24}$

\section{Optimisme Masa Depan Siswa SMK Al-Mahrusiyah}

Tingkat optimisme masa depan siswa SMK berdasarkan hasil penelitian menunjukkan mayoritas memiliki tingkat optimisme sedang, sebagian yang lain pada tingkat tinggi dan rendah. Siswa SMK yang berada di pondok pesantren menyadari persaingan di dunia kerja lebih luas dari pada kehidupan mereka di lingkungan pesantren, keoptimisan dalam menghadapi kehidupan setelah lulus sangat memengaruhi dalam kesungguhan belajar selama di lingkungan sekolah. Sikap optimisme sangat dibutuhkan untuk mencapai masa depan yang mereka inginkan. Di sisi lain keunggulan yang dimiliki dan tidak diragukan siswa yang berstatus santri, mereka mempunyai nilai lebih dalam pengetahuan agama.

\footnotetext{
${ }^{22}$ Supriatna et al., "Konsep dan Implementasi Pendidikan Karakter di Sekolah Menengah Kejuruan (SMK) Berbasis Pondok Pesantren," 18.

${ }^{23}$ Eka Marwati, Nanik Prihartanti, and Wisnu Sri Hertinjung, "Pelatihan Berpikir Optimis untuk Meningkatkan Harga Diri pada Remaja di Panti Asuhan," Indigenous: Jurnal Ilmiah Psikologi 1, no. 1 (May 27, 2016): 24, https://doi.org/10.23917/indigenous.v1il.1790.

${ }^{24}$ M. Ali Basyaruddin and M. Arif Khoiruddin, "Peran Pembina Asrama dalam Pembelajaran di Pondok Pesantren," Jurnal Pendidikan Islam 4, no. 1 (September 21, 2020): 3.
} 
Mereka sudah terbiasa membagi waktu dengan terlatih hidup mandiri di pondok pesantren yang jauh dari keluarga.

Selain itu siswa yang memutuskan sekolah formal di pondok pesantren AlMahrusiyyah memiliki tugas lebih berat daripada santri yang hanya sekolah diniyah saja, kondisi seperti ini sangat memungkinkan muncul persoalan dalam melaksanakan aktivitas kegiatan sehari-hari. Memang berat untuk memutuskan dan menjalani pilihan tersebut tanpa ada orientasi yang jelas pada masa depannya. Kemampuan santri akan penilaian diri sendiri dan menghargai seluruh potensi yang miliki, akan menumbuhkan sikap optimis yang tinggi untuk menggapai cita-cita yang diharapkan. Sifat optimisme harus selalu ditingkatkan dari masa ke masa mengingat pentingnya optimisme yang berperan penting dalam proses penyesuaian pada kondisi maupun masalah yang sulit. Optimisme merupakan salah satu dasar kebahagian, berkaitan erat dengan bagaimana cara kita menjelaskan pada diri kita sendiri berbagai peristiwa dialami.

Siswa yang tidak optimis dan tidak bisa menerima kritikan orang lain untuk mengubah kehidupannya menjadi lebih baik menyebabkan siswa tidak mampu berkembang, ketakutan yang biasa dialami sebenarnya hanyalah pikiran mereka sendiri. Untuk itu sikap optimis harus ditanamkan dalam diri agar apa yang dilakukan membawa jalan kesuksesan. Siswa yang mampu menghargai kelebihan yang dimilikinya akan mampu berpikir optimis untuk ke depannya. Apalagi menjadi santri sudah punya nilai yang lebih dibanding mereka yang hanya bersekolah formal, maka siswa SMK akan mampu memaksimalkan kemampuan yang mereka miliki, maka rasa minder akan tergantikan dengan kepuasan yang sesungguhnya.

Faktor yang memengaruhi optimisme yaitu faktor lingkungan. Anak akan belajar optimis dari orang tua ataupun orang-orang di sekitarnya. Shapiro juga mengungkapkan bahwa kecenderungan anak akan meniru pola dan perilaku dari orang tua maupun lingkungan tempat tinggalnya, termasuk menyerap aspek-aspek yang baik dan yang buruk seperti halnya orang tuanya bersikap optimis atau sebaliknya, maka anak cenderung bersikap seperti itu juga. Menurut Seligman, optimisme merupakan pandangan menyeluruh yang memberikan makna bagi diri untuk berpikir secara positif dan melihat hal-hal yang baik. Terbentuknya pola pikir optimis pada diri seseorang apakah bernilai atau tidak tergantung bagaimana sudut pandang dan perasaan pada dirinya.

Siswa SMK Pondok Pesantren Al-Mahrusiyah dapat menumbuhkan sifat optimisme dengan mengenali pikiran pesimistis lalu menentangnya. Sebagaimana dalam ajaran agama mengajarkan kepada kita semua untuk optimis dan tidak berputus asa. Peluang besar dapat 
meningkatnya sikap optimisme masa depan mengingat santri pondok pesantren dikenal lebih kuat dan tabah bila jika dihadapkan dengan permasalahan dalam kehidupan, santri memahami dan memiliki kebermaknaan dalam hidup dan sadar akan hikmah di balik permasalahan yang sedang dihadapi. ${ }^{25}$ Ajaran agama menjadi salah satu faktor penting yang menjiwai nilai-nilai kemanusiaan, perilaku, dan pengalaman yang ada. Pada ajaran agama terdapat kekuatan yang luar biasa dari keyakinan kepada Tuhan, yang kepercayaan dapat memberikan kekuatan spiritual pada manusia, membantu mereka dalam kehidupan dan memberikan efek positif pada pikiran.

Pada kehidupan pesantren seorang kiai adalah contoh orang yang memiliki optimisme sangat tinggi. Kiai percaya bahwa ketika permasalahan datang, maka Tuhan akan menyiapkan dengan sesuatu hal yang menyenangkan pada waktunya. Kiai juga menghadapinya dengan penuh percaya diri karena memiliki kesadaran penuh akan kehadiran Tuhan. Selain itu, kiai juga percaya bahwa tidak ada yang harus disalahkan atas semua permasalahan yang terjadi, karena masalah itu datang dari Tuhan, selain dari ajaran Islam, optimisme juga didapat dari pengalaman sehari-hari saat berinteraksi dengan kiai pendahulunya yang sudah memiliki kehidupan optimis. ${ }^{26}$

\section{Penutup}

Hasil penelitian menunjukkan bahwa terdapat pengaruh signifikan antara self-esteem dengan optimisme masa depan sebesar 12,2\% dengan signifikasi sebesar 0,013, artinya terdapat kontribusi signifikan self-esteem dan optimisme masa depan siswa SMK AlMahrusiyah. Tingkat self-esteem siswa SMK Al Mahrusiyah mayoritas siswa berada pada tingkat self-esteem sedang sebesar $64 \%$, sebagian lain memiliki self-esteem tinggi sebesar $20 \%$ dan sebagian lebih kecil memiliki tingkat self-esteem rendah sebesar 16\%. Hasil tersebut siswa sudah memenuhi sebagian besar aspek self-esteem dan dapat berkembang seiring terciptanya di lingkungan sosial yang positif di pondok pesantren.

Bagi peneliti selanjutnya disarankan memperjelas self-esteem secara lebih spesifik dan juga memperhatikan beberapa hal seperti pemilihan lembaga, sampel, instrumen penelitian dan jumlah responden. Dikarenakan peneliti ini hanya menggunakan dua variabel, diharapkan peneliti selanjutnya untuk menambah variabel dan metode penelitian, seperti

25 Fuad Nashori, "Kekuatan Karakter Santri," Millah 11, no. 1 (August 20, 2011): 204, https://doi.org/10.20885/millah.vol11.iss1.art10.

${ }^{26}$ Aulia and Widayat, "Optimism Overview of a Kyai in Life and Running an Islamic Boarding School." 
dengan memadukan antara kuantitatif dan kualitatif agar bisa diperoleh gambaran menyeluruh mengenai kondisi siswa.

\section{Daftar Rujukan}

A'isyah, Siti. “SMK Pesantren: Sebuah Penelusuran Akar Ideologi Pendidikan.” Dirasat: Jurnal Manajemen dan Pendidikan Islam 3, no. 1 (December 1, 2017): 81-102. https://doi.org/10.26594/dirasat.v3i1.986.

Aisyah, Siti, Susatyo Yuwono, and Saifuddin Zuhri. "Hubungan Self Esteem dengan Optimisme Masa Depan Santri Program Tahfidz di Pondok Pesantren Al Muayyad Surakarta dan Ibnu Abbas Klaten. Jurnal Indeginous.” Indigenous: Jurnal Ilmiah Psikologi 13, no. 2 (November 12, http://journals.ums.ac.id/index.php/indigenous/article/view/2598.

Alan L McGinnis. Kekuatan Optimisme. Jakarta: Mitra Utama, 1995.

Astari, Ajeng. Wawancara dengan Pengurus Pondok Pesantren Al-Mahrusiyyah, July 23, 2020.

Aulia, Sayidah, and Iwan Widayat. "Optimism Overview of a Kyai in Life and Running an Islamic Boarding School,” 6:1. Kyoto, Japan: ISEP, 2017.

Bagana, Elpida, Andreea Raciu, and Luminita Lupu. "Self Esteem, Optimism and Exams' Anxiety among High School Students." Procedia - Social and Behavioral Sciences, 2nd World Conference on Psychology, Counselling and Guidance - 2011, 30 (January 1, 2011): 1331-38. https://doi.org/10.1016/j.sbspro.2011.10.258.

Barliana, Mukhammad Syaom, Djohar Maknun, and Kunthi Herman. "Evaluasi Atas Kebijakan Peningkatan Rasio Siswa SMK:SMA Ditelaah Dari Kesiapan Sarana Dan Prasarana." Invotec 6, no. 2 (2010). https://doi.org/10.17509/invotec.v6i2.6087.

Basyaruddin, M. Ali, and M. Arif Khoiruddin. "Peran Pembina Asrama dalam Pembelajaran di Pondok Pesantren.” Jurnal Pendidikan Islam 4, no. 1 (September 21, 2020): 1-10.

Hepper, E.G. "Self-Esteem." In Encyclopedia of Mental Health, 80-91. Elsevier, 2016. https://doi.org/10.1016/B978-0-12-397045-9.00076-8.

Holloway, Franklin, ed. Self-Esteem: Perspectives, Influences and Improvement Strategies. Psychology of Emotions, Motivations and Actions. New York: Nova Science Publishers, Inc, 2016.

Marwati, Eka, Nanik Prihartanti, and Wisnu Sri Hertinjung. "Pelatihan Berpikir Optimis untuk Meningkatkan Harga Diri pada Remaja di Panti Asuhan." Indigenous: Jurnal Ilmiah Psikologi 1, no. 1 (May 27, 2016): 23-31. https://doi.org/10.23917/indigenous.v1i1.1790.

Multasih, Endang, and Bambang Suryadi. "Pengaruh Self-Esteem Dan Dukungan Sosial Terhadap Optimisme Masa Depan Anak Jalanan Di Rumah Singgah Jakarta Selatan." Tazkiya: Journal of Psychology 1, no. 1 (February 21, 2019). https://doi.org/10.15408/tazkiya.v18i1.9377.

Nashori, Fuad. "Kekuatan Karakter Santri." Millah 11, no. 1 (August 20, 2011): 203-19. https://doi.org/10.20885/millah.vol11.iss1.art10.

Rahman, Kholilur. "Inovasi Pendidikan Keahlian Sekolah Menengah Kejuruan Berbasis Pesantren di Kabupaten Banyuwangi." Jurnal Pendidikan Agama Islam (Journal of 
Islamic Education Studies) 6, no. 2 (2018): 225-52. https://doi.org/10.15642/jpai.2018.6.2.225-252.

Rochayati, Umi, Z. Zamroni, and Putu Sudira. "Islamic Boarding School Based Vocational Education: A Case Study on SMK Syubbanul Wathon Tegalrejo Magelang." Jurnal Pendidikan Vokasi 7, no. 3 (2017): 262-74. https://doi.org/10.21831/jpv.v7i3.12450.

Seligman, Martin E. P. Learned Optimism. New York, NY: Knopf, 1991.

Sidabalok, Ruth Novianti, Winida Marpaung, and Yulinda Septiani Manurung. "Optimisme dan Self Esteem pada Pelajar Sekolah Menengah Atas." Philanthropy: Journal of Psychology 3, no. 1 (July 25, 2019): 48-58. https://doi.org/10.26623/philanthropy.v3i1.1319.

Sudiyatno, Sudiyatno, Mingchang Wu, Agus Budiman, Didik Purwantoro, Tuatul Mahfud, and Ibnu Siswanto. "The Effect of Instructional Quality on Vocational Students' Academic Achievement and Career Optimism." International Journal of Innovation, Creativity and Change 10, no. 7 (2019): 244-60.

Supriatna, Ece, Ending Bahruddin, Didin Hafidhuddin, and Didin Saefuddin. "Konsep dan Implementasi Pendidikan Karakter di Sekolah Menengah Kejuruan (SMK) Berbasis Pondok Pesantren." Ta'dibuna: Jurnal Pendidikan Islam 3, no. 2 (September 5, 2014): 100-114. https://doi.org/10.32832/tadibuna.v3i2.564.

University of Athens, Greece, Argyro Charokopaki, Katerina Argyropoulou, and University of Athens, Greece. "Optimism, Career Decision Self-Efficacy and Career Indecision Among Greek Adolescents." Education Quarterly Reviews 2, no. 1 (March 30, 2019). https://doi.org/10.31014/aior.1993.02.01.52. 